\title{
TAXONOMY OF EPYRIS (HYMENOPTERA, BETHYLIDAE) FROM PARANÁ, BRAZIL
}

\author{
Lucyane Moreira dos Santos ${ }^{1,2}$ \\ Celso Oliveira Azevedo ${ }^{1,3}$
}

\begin{abstract}
Epyris rotundus sp. nov. and Epyris cochlear sp. nov., from southern Brazil, are described and illustrated. Epyris longus Corrêa \& Azevedo, 2002, E. argentinicus Evans, 1969, E. angustatus Evans, 1969, E. perpolitus Evans, 1969, E. parallelus Evans, 1969, E. distinctus Corrêa \& Azevedo, 2002, E. variatus Corrêa \& Azevedo, 2002, E. jugatus Evans, 1969, E. intermedius Evans, 1969 and E. depressigaster Evans, 1966 are recorded for the first time to Paraná, Brazil.
\end{abstract}

KEYWORDS. Epyrinae, Epyris, Hymenoptera, southern Brazil, taxonomy.

\section{INTRODUCTION}

Epyris Westwood, 1832 belongs to subfamily Epyrinae, with about 64 species in the Neotropical region. There are 29 species recorded to Brazil, from the states of Amapá, Pará, Mato Grosso, Espírito Santo, Rio de Janeiro, Paraná and Santa Catarina. Two species were recorded to Paraná State, E. crassifemur Evans, 1969 and E. marcapata Evans, 1969. Thirteen species from Paraná are recognized, two of them described as new and ten recorded for the first time to the state.

The material examined was provided by the Coleção de Entomologia Padre J. S. Moure, Universidade Federal do Paraná, Brazil (DZUP). The nomenclature of integument sculpture follows HARRIS (1979) and the terminology generally EvANs (1969). Main measurements and indices used are: DAO, diameter of anterior ocellus; distance from posterior ocellus to vertex crest; HE, height of eye; LFW, length of fore wing; LH, length of head; OOL, ocello-ocular line; VOL, vertex-ocular line; WF, width of frons; WH, width of head; WOT, width of the ocellar triangle.

1. Universidade Federal do Espírito Santo, Departamento de Biologia, Av. Marechal Campos 1468, Maruípe, 29.040-090 Vitória, ES, Brazil. (lucyanes@bol.com.br; cazevedo@npd.ufes.br)

2. Fellowship IC CNPq.

3. Researcher CNPq. 
tricostatus species group

\section{Epyris longus Corrêa \& Azevedo, 2002}

Epyris longus CôRrea \& Azevedo, 2002:129, fig. 1, type locality: Espírito Santo, Brazil, holotype in Universidade Federal do Espírito Santo (UFES).

Distribution. Espírito Santo; it is recorded for the first time to Paraná, Brazil.

Material examined. BRAZIL, Paraná: Fênix (Reserva Estadual ITCF), f, 20.VI.1988, Malaise trap, Profaupar survey (DZUP).

\section{Epyris argentinicus Evans, 1969}

Epyris argentinicus Evans, 1969:230, figs. 12, 13, 18, 43, type locality: Tucumán, Argentina, holotype in Instituto Miguel Lillo (FIML).

Distribution. Tucumán, Argentina; Santa Catarina and it is recorded for the first time to Paraná, Brazil.

Material examined. BRAZIL, Paraná: Ponta Grossa (Vila Velha, Reserva IAPAR, BR 376), §; Telêmaco Borba (Reserva Samuel Klabin), C. All collected in 06.X.1986-11.I.1988, Malaise trap, Profaupar survey (DZUP).

\section{Epyris angustatus Evans, 1969}

Epyris angustatus Evans, 1969:236, fig. 21, type locality: Santa Catarina, Brazil, holotype in Museum of Comparative Zoology (MCZ).

Distribution. Santa Catarina; it is recorded for the first time to Paraná, Brazil.

Variation. All the specimens have tibiae not very spinose as the type.

Material examined. BRAZIL, Paraná: Jundiaí do Sul (Fazenda Monte Verde), đ; Ponta Grossa (Vila Velha, Reserva IAPAR, BR 376) 3 ‡; Fênix (Reserva Estadual ITCF), ॄ; Colombo (EMBRAPA, BR $476 \mathrm{Km} \mathrm{20),} \mathrm{\subsetneq .} \mathrm{All} \mathrm{collected} \mathrm{in} \mathrm{13.X.1986-19.X.1987,} \mathrm{Malaise} \mathrm{trap,} \mathrm{Profaupar} \mathrm{survey} \mathrm{(DZUP).}$

\section{Epyris rotundus sp. nov.}

(Figs. 1-3)

\section{Description. Holotype ${ }^{\circ}$, length $3.75 \mathrm{~mm}$; LFW $2.25 \mathrm{~mm}$.}

Color: body and clypeus black; apex of metasoma dark castaneous; mandibles, antennae, palpi castaneous; legs dark castaneous; wings subhyaline.

Head (fig. 1): mandibles tridentate, of moderate breadth. Clypeus sub-angulate. First four antennal segments in a ratio of 12:6:5:8; segment III 1.2x longer than thick; segment XI 1.6x as long as thick; short flagellar pubescence, with few erect setae. Eyes very weakly hairy. Frons coriaceous, punctures shallow. WH 0.91x LH; WF 0.62x WH; WF 1.18x HE; OOL 1.3x WOT; frontal angle of ocellar triangle acute; distance from the posterior ocelli to vertex crest 1.27x DAO. Vertex rounded. VOL 0.47x HE. Mesosoma (fig. 1): thorax coriaceous and punctuated as frons. Notauli complete, widened and convergent behind, distant each other $2.5 \mathrm{x}$ their posterior width; parapsidal furrows complete, slightly 
widened behind. Scutellar pits elliptical, distant each other 1.56x its length, joined by a very narrow furrows. Propodeal disc $1.32 \mathrm{x}$ as wide as long; median carina complete, discal carinae straight, slightly longer than half of the disc and slightly convergent behind, space between discal carinae striate; lateral of propodeum and declivity microstriate. Mesopleuron with a complete and large fovea with a deep triangular central pit. Mid tibiae spinose. Metasoma: polished up to third segment and weakly coriaceous behind.

Genitalia (figs. 2, 3): paramere wide, $1.58 x$ longer than basiparamere; cuspis slightly higher than half of paramere; aedeagus as high as cuspis, apex emarginate medially; apodeme with base directed outward.

Type material. BRAZIL, Paraná: Jundiaí do Sul (Fazenda Monte Verde), holotype ó, 07.XII.1987, Malaise trap, Profaupar survey (DZUP). Paratypes: Fênix (Reserva Estadual ITCF), హ; Jundiaí do Sul (Fazenda Monte Verde), o; Ponta Grossa (Vila Velha, Reserva IAPAR, BR 376), O; São José dos Pinhais (Serra do Mar, BR 277 Km 54), ơ. All collected in 10.XI.1986-04.I.1988, Malaise trap, Profaupar (DZUP).

Variation. Color of antennae dark castaneous; discal carinae of propodeum longer near the basal.

Remarks. Epyris rotundus belongs to tricostatus group and runs to E. marcapata Evans, 1969 in the key by Evans (1969), but it has paramere with rounded apex, aedeagus as high as cuspis; E. marcapata has paramere with apex truncate and aedeagus shorter than cuspis.

Etymology. Specific name refers to the rounded apex of paramere.

rufipes species group

\section{Epyris perpolitus Evans, 1969}

Epyris perpolitus Evans, 1969:307, figs. 89, 120, type locality: Rio de Janeiro, Brazil, holotype in Townes Collection.

Distribution. Rio de Janeiro, Santa Catarina; it is recorded for the first time to Paraná, Brazil.

Variation. The paramere can be longer than in the type and the longest females show texture stronger than in the small specimens.

Material examined. BRAZIL, Paraná: São José dos Pinhais (Serra do Mar, BR 277 Km 54),

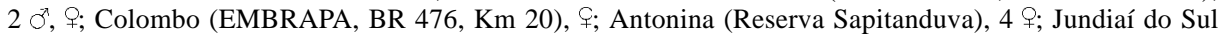
(Fazenda Monte Verde), 41 §. All collected in 11.VIII.1986-25.VII.1988, Malaise trap, Profaupar survey (DZUP).

\section{Epyris parallelus Evans, 1969}

Epyris parallelus Evans, 1969:309, figs. 118, 119, 123, type locality: Tucumán, Argentina, holotype in FIML.

Distribution. Tucumán, Argentina; Santa Catarina and it is recorded for the first time to Paraná, Brazil.

Variation. The paramere and cuspis are longer than those of type series. 
Material examined. BRAZIL, Paraná: Guarapuava (Estação Águas Santa Clara), ơ; Telêmaco Borba (Reserva Samuel Klabin), ऊ̧. All collected in 27.X.1986-12.X.1987, Malaise trap, Profaupar survey (DZUP).

\section{Epyris crassifemur Evans, 1969}

Epyris crassifemur Evans, 1969:303, figs. 122, 126, type locality: Santa Catarina, Brazil, holotype in MCZ.

Distribution. Espírito Santo, Paraná and Santa Catarina, Brazil.

Variation. In relation to the type series, cuspis can be bigger, aedeagus can have the same length of paramere, paramere in lateral view can be wider and slightly arched, females can be slightly more coriaceous and the scutellar pits separated by little less than twice their own diameters.

Material examined. BRAZIL, Paraná: Jundiaí do Sul (Fazenda Monte Verde), 8 \%, 14 \&; Telêmaco Borba (Reserva Samuel Klabin), 6 ơ; Guarapuava (Estação Águas Santa Clara), ơ; Colombo (EMBRAPA, BR 476, Km 20), ơ; Fênix (Reserva Estadual ITCF), ๆ; Ponta Grossa (Vila Velha, Reserva IAPAR, BR 376), Ғ. All collected in 11.VIII.1986-25.VII.1988, Malaise trap, Profaupar survey (DZUP).

\section{Epyris distinctus Corrêa \& Azevedo, 2002}

Epyris distinctus Côrrea \& Azevedo, 2002:130, figs. 6-8, type locality: Espírito Santo, Brazil, holotype in UFES.

Distribution. Espírito Santo; it is recorded for the first time to Paraná, Brazil.

Variation. In relation to the type series, the paramere can be as long as wide, in lateral view, slightly larger than basiparamere and cuspis thin.

Material examined. BRAZIL, Paraná: Ponta Grossa (Vila Velha, Reserva IAPAR, BR 376), 4 \%; Telêmaco Borba (Reserva Samuel Klabin), 2 o; Jundiaí do Sul (Fazenda Monte Verde), 16 హ. All collected in 04.VIII.1986-06.X.1988, Malaise trap, Profaupar survey (DZUP).

\section{Epyris variatus Corrêa \& Azevedo, 2002}

Epyris variatus CôRrea \& Azevedo, 2002:132, figs. 9-12, type locality: Espírito Santo, Brazil, holotype in UFES.

Distribution. Espírito Santo; it is recorded for the first time to Paraná, Brazil.

Material examined. BRAZIL, Paraná: Jundiaí do Sul (Fazenda Monte Verde), 39 ö; 01.IX.198615.VIII.1988, Malaise trap, Profaupar survey (DZUP).

\section{Epyris cochlear sp. nov.}

(Figs. 4-6)

Description. Holotype $\sigma$. Length $4.07 \mathrm{~mm}$; LFW $2.70 \mathrm{~mm}$.

Color: body and clypeus black; mesosoma castaneous; mandibles, antennae and tegulae dark castaneous; palpi light castaneous; legs castaneous; wings subhyaline.

Head (fig. 4): mandibles forming a cutting edge. Clypeus angulate. First four antennal 
segments in a ratio of 11:6:6:8; segment III 1.7x as long as thick; segment XI 2x as long as thick; flagellar pubescence short. Eyes very weakly hairy. Frons coriaceous, punctures small and shallow. WH 1.16x LH; WF 1.28x HE; WF 0.61x WH; OOL 1.31x WOT; frontal angle of ocellar triangle acute; distance from the posterior ocelli to vertex crest $0.44 \mathrm{x}$ DAO. Vertex rounded. Temples parallel. VOL 0.71x HE. Mesosoma (fig. 4): thorax coriaceous and punctuated as frons, except anterior half of mesoscutum, without punctures. Notauli complete, narrow, nearly straight, with a median callus and rounded corners; parapsidal furrows narrow and incomplete anteriorly. Scutellar pits elliptical and small, distant each other $3 \mathrm{x}$ its length. Propodeal disc $1.15 \mathrm{x}$ as wide as long; median carinae complete, with two pairs of thin discal carinae present on anterior half; posterior corners foveolate; declivity with a median carinae. Mesopleuron with a complete and large fovea which occupies all surface of mesopleuron, with a deep rounded central pit.

Genitalia (figs. 5, 6): margin of paramere membranous and basiparamere longer than paramere; paramere spoon-shaped, with narrow base and wide and rounded apex; aedeagus short and lower than cuspis, median area strongly emarginated; apodeme with base directed outward and different apex; cuspis laminar, surface vertical and $0.68 x$ length of paramere.

Type material. BRAZIL, Paraná: Telêmaco Borba (Reserva Samuel Klabin), holotype ơ, 11.VIII.1986, Malaise trap, Profaupar survey (DZUP). Paratype: Ponta Grossa (Vila Velha, Reserva IAPAR, BR 376), 3, 21.IV.1988, Malaise trap, Profaupar (DZUP).

Variation. Scape darker.

Remarks. Epyris cochlear belongs to rufipes group and runs to E. crassifemur Evans, 1969 in the key by Evans (1969), but it has very different genitalia, with paramere wide with base narrow and spoon-shaped, basiparamere longer than paramere.

Etymology. Specific name cochlear is a noun in apposition. It refers to the spoonshaped paramere.

flavicrus species group

\section{Epyris jugatus Evans, 1969}

Epyris jugatus Evans, 1969:348, figs. 158, 160, 167, type locality: Tucumán, Argentina, holotype in MCZ.

Distribution. Tucumán, Argentina; Santa Catarina and it is recorded for the first time to Paraná, Brazil.

Variation. In relation to the types series, males can have paramere 2.0x longer than basiparamere, apex of the paramere angulate and membranous, apex of the aedeagus emarginated and female can have head longer than wide, WH $0.88 \times \mathrm{LH}$.

Material examined. BRAZIL, Paraná: São José dos Pinhais (Serra do Mar, BR 277 Km 54), ơ; Telêmaco Borba (Reserva Samuel Klabin), 2 З ; Ponta Grossa (Vila Velha, Reserva IAPAR, BR 376), 5 đ; Jundiaí do Sul (Fazenda Monte Verde), 127 3, क; Fênix (Reserva Estadual ITCF), 7 \& Antonina (Reserva Sapitanduva), ठ․ All collected in 04.VIII.1986-13.VI.1988, Malaise trap, Profaupar survey (DZUP). 

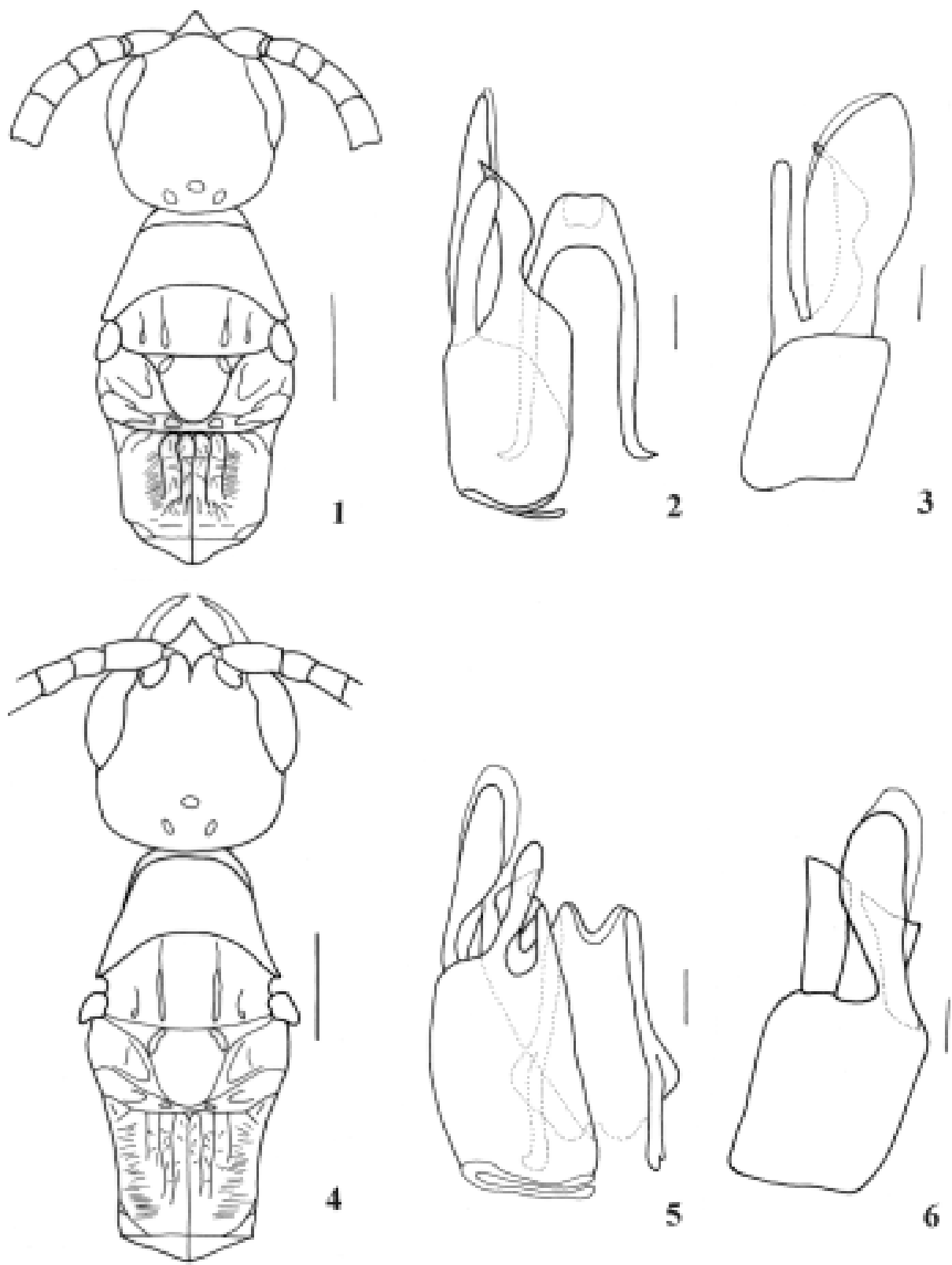

Figs. 1-6. Epyris rotundus sp. nov.: 1, head and mesosoma, dorsal; male genitalia: 2, ventral; 3, lateral. Epyris cochlear sp. nov.: 4, head and mesosoma, dorsal; male genitalia: 5, ventral; 6, lateral (scale bars $=0.2 \mathrm{~mm}$ ). 


\section{depressigaster species group}

\section{Epyris intermedius Evans, 1969}

Epyris intermedius Evans, 1969:333, 334, fig. 150, type locality: Mato Grosso, Brazil, holotype in Carnegie Museum.

Distribution. Mato Grosso, Santa Catarina; it is recorded for the first time to Paraná, Brazil.

Variation. Ten specimens show weak striation on abdominal sternite.

Material examined. BRAZIL, Paraná: Jundiaí do Sul (Fazenda Monte Verde), 8 q; Fênix (Reserva Estadual ITCF), §; Ponta Grossa (Vila Velha, Reserva IAPAR, BR 376), 2 ‡. All collected in 20.X.1986-11.IV.1988, Malaise trap, Profaupar survey (DZUP).

\section{Epyris depressigaster Evans, 1966}

Epyris depressigaster Evans, 1966:275, 276, type locality: Santa Catarina, Brazil, holotype in Natural History Museum.

Distribution. Santa Catarina; it is recorded for the first time to Paraná, Brazil.

Variation. This specimen shows weak striate on the abdominal sternite.

Material examined. BRAZIL, Paraná: Fênix (Reserva Estadual ITCF), f, 08.IX.1986, Malaise trap, Profaupar survey (DZUP).

Acknowledgments. To setor of Genetics (UFES) by the loan of camera lucida; to curator K. Zanol (DZUP) for the loan of the material examined.

\section{REFERENCES}

CorrêA, M. S. \& Azevedo, C. O. 2002. Systematic of Epyris (Hymenoptera, Bethylidae) from Biological Reserve of Duas Bocas, Espírito Santo, Brazil. Revta bras. Ent., Curitiba, 46(2):129132.

Evans, H. E. 1966. Further studies on Neotropical Epyrini (Hymenoptera, Bethylidae). Psyche, Cambridge, 72(4):265-278.

1969. A revision of the genus Epyris in the Americas (Hymenoptera, Bethylidae). Bull. Mus. comp. Zool., Cambridge, 95(2):181-352.

Harris, R. A. 1979. A glossary of surface sculpturing. Occas. Pap. Ent., Sacramento, 28:1-31.

Recebido em 14.08.2002; aceito em 07.02.2003. 